Ronald D. Patkus

\title{
MUSICAL MIGRATIONS: A CASE STUDY OF THE TERESA CARREÑO PAPERS
}

WHEN WE FOCUS on the migration of collections, we generally think of the movement of these collections into our own repositories, typically in North America. But as we widen our focus, we see other types of collection migrations, including those from America to other countries. What is more, we can even see cases where both of these movements-to and from America-apply to a single collection. Though less frequent than single migrations, multiple migrations raise a variety of key issues for scholars, librarians, and others. The papers of Teresa Carreño, the Venezuelan pianist, composer, and teacher, provide a case in point. By examining their history and current situation, we bring to light some of the complex issues involved in many collection migrations and consider some general implications for the work of curators and librarians.

Teresa Carreño was born in Caracas, Venezuela, in 1853, to a prominent family for her granduncle was Simon Bolivar, and her father, Manuel Antonio, was Minister of Finance. It was also a musical family: her father was an amateur pianist and her grandfather, Caetano Carreño, was an important composer. As a child, Carreño displayed amazing ability at the piano and was quickly recognized as a prodigy. To launch her musical career, her family began to travel to the United States and Europe before she reached the age of 9 . While still a young girl, she composed and performed concerts around the world. She also came to know some of the key musicians of her day, including Rossini, Liszt, and Saint-Saens. Her touring continued into adulthood. Although she briefly experimented with a career as an opera singer, by 1889 , she had settled down in Berlin. From this base she performed with the major orchestras of Europe and taught music. Among her correspondents were Edward MacDowell, Amy Beach, and Edvard Grieg. Despite a busy and sometimes tempestuous personal life (she was married four times and had several children), she continued to promote her career. In the early years 
of the twentieth century, she made two world tours, visiting places as far away as South Africa and New Zealand. Carreño was known as "the Walküre of the Piano," a name that reflected her great talent and skill. ${ }^{1}$ During a tour of Cuba in 1917, she became ill and died a short time later in New York. At the time of her death, a New York Times obituary called her "the most famous of women pianists." ${ }^{2}$ Her book, Possibilities of Tone Color by Artistic Use of Pedals, was published posthumously. In sum, Carreño was an important figure in the world of music during the late nineteenth and early twentieth centuries. Her accomplishments are especially noteworthy when one considers the difficulties women had in establishing independent careers at the time.

The origin of the Carreño papers can be traced back to the $1860 \mathrm{s.}^{3}$ We know that Carreño's father deliberately and carefully preserved a precious scrapbook chronicling the accomplishments of his daughter. Carreño herself seems to have continued the practice of maintaining a scrapbook in later years, though perhaps not with quite the same devotion and attention. Regardless, the musician also accumulated a great amount of other material relating to her life and work, and much of it must have been at her home in Berlin, where she resided with her family for twenty-two years, until 1917, when she moved to New York. She lived in New York for just a few months before she fell ill and died. At the time of her death, Carreño left behind an extensive, rich, and diverse collection of papers and other personal possessions. Many suitcases had been moved to New York from Berlin, and these must have included Carreño's papers, though we cannot be absolutely sure. Naturally enough, Arturo Tagliapietra, the musician's husband at the time, was executor of Carreño's estate, along with a Clarence M. Woolley. Together they had jurisdiction over the papers. Unfortunately, little evidence survives to clarify what happened to the papers in the years immediately following Carreño's death.

We do know, however, that by the late 1920s one of Carreño's former students, Marta Milinowski, had become engaged in writing a biography of the pianist and that she had been in touch with the estate executors about using portions of the extant papers in her research. Mi-

1. Carreño's obituary makes reference to this title; see "Mme.Teresa Carreno, Famous Pianist, Dies," New York Times (13 June 1917).

2. Ibid.

3. For a full description of the papers, see Brian Mann, "The Carreño Collection at Vassar College," Notes 47, no. 4 (June 1991): 1064-83. 
linowski was a Vassar graduate of the class of 1907 who later, in 1930, came back to the college as a faculty member in the music department, replacing a member who was retiring. This position allowed her to continue working on her biography of Carreño. Milinowski's work was eventually completed and published by Yale University Press in $1940 .{ }^{4}$

It is unclear where and when Milinowski was first given access to the papers. But certainly Arturo Tagliapietra worked closely with her. Vassar College Music Department files indicate that by the summer of 1931, many of Carreño's papers had actually been moved to the department's home in Skinner Hall, presumably from New York, although possibly from Europe or elsewhere. ${ }^{5}$ Apparently Tagliapietra came to Vassar and helped Milinowski sort through various materials, but despite the close connection between the estate and the college, the papers remained in the possession of the estate for another decade.

In 1941, though, the papers were purchased outright by Vassar College, largely through the efforts of Milinowski. ${ }^{6}$ The timing suggests that nothing was done until the professor completed her research and writing. The collection that came to Vassar, as noted, had great breadth and depth. It included music manuscripts, literary manuscripts, correspondence, scrapbooks and memorabilia, diaries, legal documents, printed matter, photographs, artwork, and realia. Among the most interesting items were original manuscripts of works by Carreño, Edward MacDowell, and Amy Beach; letters from Saint-Saens, Grieg, Rossini, and many others; rare ephemera relating to Carreño's career; and a large collection of printed music by Carreño and others. It appears that Vassar's music department was especially interested in the publications, as they supported the music curriculum and added significantly to the holdings in the Music Library.

Then an odd thing happened. A decade later, during the administration of President Sarah Blanding, the college decided that it did not really want much of the collection after all. Representatives of Vassar entered into negotiations with the Venezuelan government to move portions of the collection to the National Library in Carreño's homeland. According to a 1956 music department annual report, the college initially did not

4. Though dated, Milinowski's biography remains an important source. See Marta Milinowski, Teresa Carreño: "by the Grace of God" (New Haven: Yale University Press, 1940).

5. Mann, "The Carreño Collection," 1065.

6. Ibid., 1064 . 
want to retain anything other than the published music; in fact, it was noted that this was really the only reason for having acquired the collection in the first place. ${ }^{7}$ This point seems odd, given Professor Milinowski's research interest in the collection. In any case, Professor Milinowski was involved in sorting out what stayed at Vassar and what went to Venezuela. In the process of reviewing what would be sent to Caracas, she apparently came across many items she could not bear to part with, and so in the end these were retained by Vassar. Included were a significant number of musical manuscripts, literary manuscripts, correspondence to and from Carreño, scrapbooks, diaries, legal documents, printed materials, photographs, and artwork. Still, a great quantity of material was shipped off, including concert gowns, diaries, concert programs, reviews, and other items. In a later annual report, an administrator was pleased to note that this arrangement "released valuable space to the Music Library." 8 Thus, this remarkable collection became divided between Vassar and the Venezuelan National Library. Today, the Venezuelan material is housed at the Teatro Teresa Carreño in Caracas, a cultural center comparable to New York's Lincoln Center.

In the interest of completeness, before going further, it should be pointed out that although Vassar and the Teatro are the main repositories housing Carreño papers, other North American libraries also hold related items of interest. Even a quick search of the RLIN database shows materials held in collections at Yale, Cornell, Brown, and the Library of Congress. When viewing all of the collections together, it becomes clear that a wealth of material is available to scholars today for the study of Carreño and the musical world she inhabited. And yet at the same time one must concede that the geographical circumstances of the collection today lead to some real difficulties for researchers.

Migration, therefore, is an important theme for the Carreño papers. Parts of the collection literally moved all around the world: from South America to Europe, from Europe to the United States, from the United States back to South America. Clearly, however, the most significant migration concerns the division of the collection between Vassar in Poughkeepsie and the Teatro in Caracas. What can we learn from this history? Are there lessons for contemporary curators and scholars?

7. Ibid., 1066 .

8. Ibid. 
If we closely analyze the history of the papers, three major areas of concern emerge: acquisition, appraisal, and access. The first involves the issue of repatriation of cultural materials and the attendant role of politics in developing collections; the second concerns the determination of the ultimate disposition of cultural materials; and the third relates to the problem of making available to users a divided collection.

First, let us consider the issue of acquisition. The Carreño papers initially came to Vassar while Marta Milinowski was working on her biography. Having the materials nearby allowed her to carry out her research more easily. But the collection was not formally transferred to the college until after the publication of the biography. From the available documentation (and unfortunately there is not much), it appears that the college was interested primarily in the music publications that were considered part of Carreño's legacy because these would augment the holdings in the Music Library. The decision to acquire Carreño's papers in addition to the publications seems to have been based largely on the connection between Milinowski and Carreño. This is not an insignificant relationship and indeed provides some justification for the collection coming to Vassar. Today, the connection to Milinowski, the growth of the Special Collections Department, and the long-term ownership of the collection all argue for Vassar's maintenance of its collection. But the division of the collection in the 1950s raises the question of whether there had been present in the beginning a full commitment and understanding of the place of the collection at the college.

The division of the collection also suggests that after a decision had been made to address an apparent space problem, Carreño's nationality emerged as the most important value. At the end of her biography, Marta Milinowski wrote about the issue of repatriation as it related to the pianist's ashes. She was sorry that in an earlier visit to Venezuela she had found no proper memorial to Carreño in her homeland, although this situation did eventually change. With regard to the repatriation of the papers, there is little documentation and so it is not exactly clear how the possibility of moving the collection to Venezuela emerged. But obviously, there was a concern on the part of the principals involved (and almost certainly Milinowski) that Carreño's papers be placed in her country of birth. The subsequent establishment of a Carreño center in Caracas suggests that perhaps the migration of some of the papers to Venezuela was a political issue in addition to a human and artistic one. Because the leaders of Venezuela had proclaimed Carreño a national cul- 
tural hero, there would be political reasons for her papers, or at least a portion of them, being returned to that country. Of course, it is difficult to gauge the extent of the role of politics, but we must at least be open to considering it. Politics can be a significant issue in collecting, and it is something we must always be aware of. In the end, all of this reinforces the importance of careful consideration of how a collection fits in with an institution's collecting objectives and larger goals.

Second, the issue of appraisal is an intriguing one as it relates to the Carreño papers. (When using the term "appraisal" here, I mean the determination of what would stay at Vassar and what would be moved to Venezuela.) The migration of the Carreño papers involved a physical dimension, which in turn led to on-the-spot appraisal decisions at the time of delivery. How did Milinowski make these decisions? Did she use a set of principles for guidance? Did the National Library of Caracas play any role in stating what it felt would be of value? Did time exert any pressure on Milinowski?

The content of the two collections in some way provides evidence for what guided Milinowski. She seems to have earmarked a variety of items for both Vassar and the National Library. Letters, manuscripts, and programs went to each institution, though many works of American composers such as Edward MacDowell were retained for Vassar. Certainly, most examples of realia went to Venezuela. One thing the division tells us is that, simply speaking, space guided much of Milinowski's decision making. But in the end, this evidence does not tell us much more. As a result, it is difficult to suggest any answers to the questions about how the appraisal was actually done. But we are reminded of the importance of this aspect of collection management, particularly when collections are in the process of migrating. Though manuscript curators are presumably cognizant at all times of the issue of space in their repositories, the Carreño case study provides an unpleasant reminder of the consequences of not fully weighing it when a collection is first acquired.

Finally, we must consider the question of access. It goes without saying that the division of the collection into two separate locations has created enormous difficulties for researchers. For decades, the two collections sat in their respective repositories and those interested in these holdings simply had to travel to both Caracas and Poughkeepsie to examine materials. In a very real sense, this situation itself may well have contributed 
to scholarly neglect of Carreño. Mindful of this possibility, in recent years there has been some effort to address this situation.

At Vassar College, the collection was fully arranged and described a few years ago, and a traditional finding aid produced. The finding aid was made available on the Internet through the Special Collections Web site. ${ }^{9}$ Researchers now can access a listing of folder titles from their desktop. This has been an important first step in making known the holdings at Vassar, and Special Collections staff regularly refer to this document as part of their reference work.

But our attempt to assist researchers has not ended there. The collection has been filmed by a local preservation vendor, which is useful to Vassar, both for preservation and for current users. Our plan is to share a use copy of the microfilm with our colleagues in Caracas. In this way, a full collection will be recreated in Caracas and researchers in South America will benefit by having access to the holdings in Poughkeepsie. We hope that an exchange of this kind also may provide a stimulus for our colleagues in Caracas to have their holdings microfilmed for both preservation and access reasons. A use copy of the film then could be deposited at Vassar as well, and we would derive benefits similar to those already mentioned.

Of course, as we look forward into the twenty-first century, we must consider other ways of enhancing access besides creating finding aids (even in electronic form) and producing preservation microfilm. Particularly in a situation such as this, the potential benefits of digitization are obvious. Through digitization it would be possible to marry the two separated collections on the Internet. The problem of needing to visit two different repositories on two different continents would largely vanish. The concept of enhancing access in this way is certainly intriguing, but there are tremendous practical difficulties in trying to bring this concept to life. In addition to the usual technological challenges that confront anyone involved in the creation of digital products, a host of other problems make collaboration difficult, including great geographical distances between the repositories, and linguistic and cultural differences. But first steps first. The creation of preservation microfilm is not only of value in and of itself; in a very real way it represents the first step toward the creation of a digital product because digital images can

9. See http://specialcollections.vassar.edu/carreno. 
be produced from the film. We will therefore move forward with this part of the project and trust that we can work toward other steps in the future.

In conclusion, a study of the Carreño papers and their migration to various places alerts us to some of the central issues involved in collection building and management. Many of us who work in manuscript repositories today must confront the challenges posed by past decisions. In addressing these challenges, we first must learn about the history of our collections. At the same time, we must creatively seek ways to fulfill our obligations to the research and learning community. With this in mind, the challenges we face can become opportunities for future collaboration.

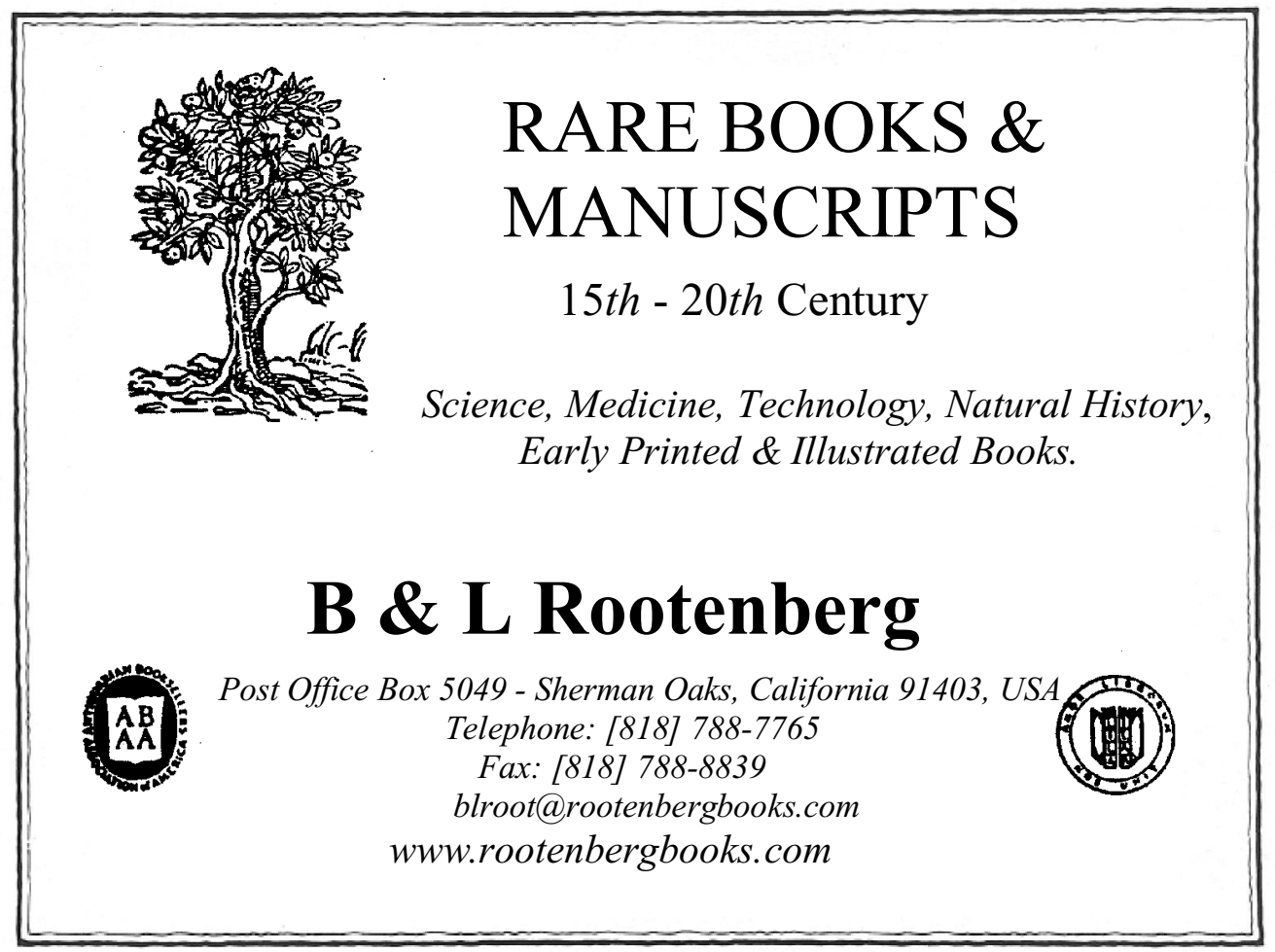

